\title{
FEMINIST THEOLOGIES: LOOKING BACK TO LOOK AHEAD*
}

\author{
Mary Elisabeth Hunt ${ }^{* *}$
}

\section{ABSTRACT}

Feminist theologies in the U.S. are the reason why attention to gender has changed religions. Feminist studies in religion and social activism go hand in hand. These twin foci form a useful backdrop for understanding contemporary feminist spirituality which is a concrete coupling of religious dynamics and feminist action. That spirituality is the product of feminist work in religion and has an impact on society. Brief descriptions of a small sample of the groups that continue to deepen this work point to a bright future for feminist theologies despite backlash and obstacles.

Keywords: Feminism; theology; social change; spirituality.

\section{TEOLOGIAS FEMINISTAS: OLHAR PARA TRÁS PARA OLHAR À FRENTE}

\section{RESUMO}

As teologias feministas nos Estados Unidos são a razão pela qual a categoria gênero tem transformado as religiões. Os estudos feministas da religião e o ativismo social têm caminhado lado a lado. Esses focos gêmeos formam um pano de fundo útil para a compreensão da espiritualidade feminista contemporânea, que é um acoplamento concreto da dinâmica religiosa e da ação feminista. Essa espiritualidade é produto do trabalho feminista na religião, e tem impacto na sociedade. Breves descrições de uma pequena amostra dos grupos que continuam a aprofundar esse trabalho apontam para um futuro brilhante para as metodologias feministas, apesar das resistências e obstáculos.

Palavras-chave: Feminismo; teologia; mudança social; espiritualidade.

* Artigo originalmente publicado na revista CARTHAGINENSIA, Vol. XXXVII, N 72, 2021, p. 323-338.

** Doutora em Teologia pela Graduate Theological Union in Berkeley, co-fundadora e co-diretora da Women's Alliance for Theology, Ethics and Ritual (WATER), em Silver Spring, nos EUA. E-mail: mhunt@hers.com 


\section{TEOLOGÍAS FEMINISTAS: MIRAR ATRÁS PARA MIRAR ADELANTE}

\section{RESUMEN}

Las teologías feministas desarrolladas en los Estados Unidos están logrando transformar las religiones a través del foco puesto en la categoría de género. Los estudios feministas sobre religión y el activismo social van de la mano y estos focos gemelos forman un telón de fondo que permite comprender la espiritualidad feminista contemporánea, que acompasa de forma concreta y práctica la dinámica religiosa y la acción feminista. Esa espiritualidad es fruto del trabajo feminista en religión y tiene un impacto en la sociedad. En este trabajo se presentarán breves descripciones de unos pocos grupos que continúan profundizando la labor feminista y que apuntan a un futuro brillante para las teologías feministas a pesar de los obstáculos y las resistencias.

Palabras clave: Feminismo; teología; cambio social; espiritualidad.

\section{INTRODUCTION}

Feminist theologies (always plural) are flowering around the world in ways unimaginable decades ago. I will look at some of the contours of this work and critically assess its future as it becomes increasingly powerful and normative.

I have been involved in the work since my graduate studies at Harvard Divinity School in the 1970s. I currently collaborate at the Women's Alliance for Theology, Ethics, and Ritual (WATER), an educational and advocacy group in suburban Washington, D.C. where we study and promote feminist studies in religion. This background provides me with a convenient fifty-year period for assessing progress and imagining next steps.

I do so from the perspective of a scholar/activist in the field, not a disinterested, disembodied researcher. My white, cisgender, late middle age, Catholic, lesbian feminist starting point in the United States conditions and limits my views. As feminist theologian Sally McFague once described her work, mine, too, is one patch in a brightly-colored quilt. When sewn together, our pieces from around the world function both as an historical record and a plan of action. 


\section{METHOD}

I begin with a general outline of feminist work in religion as it played out in the U.S. by considering how attention to gender has changed religions and how feminist studies in religion and social activism go hand in hand. These twin foci form a useful backdrop for understanding contemporary feminist spirituality which is a concrete coupling of religious dynamics and feminist action. That spirituality is the product of feminist work in religion and has an impact on society.

I conclude with a brief description of a small sample of the groups that continue to deepen this work. I point to a bright future for feminist theologies despite backlash and obstacles.

\section{HOW CONCERN ABOUT GENDER HAS CHANGED RELIGIONS}

Stirrings of feminist theologies emerged in several countries in the $19^{\text {th }}$ century, including Germany and England. I will focus on the U.S. reality, leaving those stories, those patches of the quilt, for others to tell. In July 1848, the first Seneca Falls Convention was held in the Wesleyan Chapel in that small historic town of Seneca Falls in Upstate New York. Elizabeth Cady Stanton read the "Declaration of Sentiments and Grievances" that became the basis of women's claims to equality with men, including the right to vote. It was the same suffrage leader, Elizabeth Cady Stanton, who, in 1895 with her Revising Committee, published The Woman's Bible (Elizabeth STANTON, 1895). That book is a compilation of exegeses of biblical texts having to do with women, written from women's perspectives. The collection went out of print, but it was revived in the 1970 s as interest grew in matters of women and religion.

The book was not a definitive exegetical catalogue written by experts, but the considered reflections of intelligent believers. The message of the publication was that women could and should take their religion in hand, bringing their own questions and insights to bear as part of a larger project of taking their place as equals to men in society. It was a revolutionary project because heretofore men has crafted virtually all of the religious meaning that emerged from the pulpit and the classroom without necessarily realizing that women's 
voices were missing.

Matilda Jocelyn Gage, another suffrage leader, wrote Woman, Church and State: A Historical Account of the Status of Woman through the Christian Ages (1893). She made a similar point, insisting that without change in religious teaching and practice, social change, including suffrage for women, would never happen.

A half century later, not far away in Geneva, New York, the first article cited in the English-language literature on religion and gender was written and published in 1960. Professor Valerie Saiving Goldstein of Hobart and William Smith College wrote "The Human Situation: A Feminine View" (1960). She argued that the nature of sin was different for women and men. Men, she said, err on the side of power-taking up a lot of space, making themselves known in public. Women's sin was the opposite-not taking other women seriously, trivializing themselves, multi-tasking (before the word was invented) such that women lack an organizing center.

Valerie Saiving suggested that if Jesus came to save all men from sins of pride, as some of the leading Protestant theologians of her day argued, perhaps Jesus did not come to save women at all. Quite the contrary. What 'fit' for men did not necessarily 'fit' for women: "turn the other cheek" and "be good to those who hate you" could be death sentences for women even if salvific for men. That was a new way of thinking. As I like to express it, perhaps the Bible should carry a warning like on a cigarette package suggesting that it might be dangerous to women's spiritual health.

Regardless of one's view of Valerie Saiving's work, her main contribution was to make clear that religion is gendered activity. Most scholars did not know that in 1960, and some still reject the concept today. But her insight opened many doors to new religious practices and thinking based on the now obvious idea that religion is a many-gendered thing.

Similar moves were made by Latin American male liberation theologians later that decade. They underscored the class-based nature of Christianity claiming it ought to have a "preferential option for the poor." Black male theologians made the racialized nature of Christianity obvious in their insistence that "Jesus was Black." Only later did 
women in those cohorts, Latin American and Black, step forward and weave their insights into gender for the creation of feminist liberation theology and womanist theology respectively. But the long-term result was that religion and theologies could not be understood in universal terms, one size fits all. Rather, the many partial, limited, and contextual ways in which people in varying circumstance experience religion have to be taken into account. Theology became far more complicated and inclusive thanks to the push provided by women.

Feminist work in religion progressed in tandem with the Second Wave of the women's movements and these theologies of liberation in the 1970s. Feminist philosopher and theologian In 1973 Mary Daly's signal volume Beyond God the Father (1993) set the bar high. She summarized the problem of gender as it is baptized and confirmed by Catholic theology: "If God is male, then the male is God" (1993, p. 19) she wrote, setting an agenda for change. From this simple, clear insight flowed what are now five decades of scholarship in virtually every religious tradition dealing with the implications of gender in shaping religions and society all over the world.

Investigations and changes in doctrines, practices, rituals, and especially on language and imagery of the divine, are now common in the world's religions. Whether exploring matriarchal societies and goddess worship, challenging the ban on Catholic women priests and on Orthodox Jewish women rabbis, or rereading histories of religious groups as if women mattered, rethinking ethical teachings on everything from reproductive justice to the economics of work, bringing a gender lens to every aspect of religious studies has had a deep impact.

I daresay these conversations have not usually been easy, friendly, or even, in some cases, rational. But that is all the more reason why they are important. As more and more women become religious leaders, the urgency of this conversation increases lest women simply accept and replicate the models they inherit.

The reaction to gender as a category for analysis and change remains controversial. For example, Pope Francis, stated, “A great enemy of marriage today is the theory of gender... Today, there is a global war trying to destroy marriage... they don't destroy it with weapons, but 
with ideas. It's certain ideological ways of thinking that are destroying it... we have to defend ourselves from ideological colonization" (Inés SAN MARTíN, 2016) I disagree with the Pope's assessment and find it woefully ill-informed. I doubt he could cite serious feminist scholars of religion trying to destroy anything. Rather, feminists seek to create and construct theologies on the basis of evolving insights. But Pope Francis does get one thing right, namely, that there are practical implications of gender theory in daily life that make the world safer for women and dependent children, indeed also for men, though that is less recognized.

Gender-related issues bear on the well-being of Earth and its inhabitants, both human and other. Ecofeminist work makes this concrete. If religions are ways we connect (religare, L.) with one another over shared beliefs and practices, then the quality of those connections is not trivial. Justice and equality are hallmarks of right relation in many traditions.

The interconnection between/among justice issues now frames feminist religious scholarship. Attention to gender in religion is not only about women per se. What began as a search for women and women's experiences hidden in texts, shrouded in prejudice, is now a new frame for thinking about human experience in its endless particularity. Anti-racism work, efforts to erase heterosexism, attention to the ways in which ableism rears its ugly head, all seek to decenter hegemonic masculinity, white supremacy, homo and trans hatred, body barriers, and body shaming. These analytic efforts are integrally related to the work of gender transformation in the interstructured and interconnected efforts to bring about justice and equity. They all find their intellectual and practical roots in the initial forays into gender.

The change in terms from what began as "women's studies in religion" to "feminist studies in religion," and lately to the more vanilla "gender studies" ought not to obscure the activist agenda implicit in most of the work. While some academics shy away from even the conversation about activism, it is important to acknowledge that most who are engaged in this work are not simply academically interested. Such scholar/activists are concerned to create a safer, more just, and equitable world. These are not mutually exclusive purposes. 


\section{THE RELATIONSHIP BETWEEN FEMINIST STUDIES IN RELIGION AND SOCIAL ACTIVISM}

Religion has the power to shape basic values. The editorial statement of the premier journal in the field, the Journal of Feminist Studies in Religion, co-founded by Christian feminist biblical scholar Elisabeth Schüssler Fiorenza and Jewish feminist theologian Judith Plaskow, conveys this clearly: "Its editors are committed to rigorous thinking and analysis in the service of the transformation of religious studies as a discipline and the feminist transformation of religious and cultural institutions". ${ }^{1}$ Note the reminiscences of both Stanton and Daly in that the changing dynamics of religion are put to the service of social change.

Given this history, it is not surprising that many who now work in the field of feminist studies in religion are also keenly aware of how important it is not simply to "add women and stir" as I warned years ago." Rather, we seek to change those religious beliefs and practices which run counter to the well-being of those who are marginalized whether by gender, race, sexual identity, age, ability, or the like. Obvious examples relate to reproductive justice, LGBTIQA rights, and environmental questions for which nuanced, interstructured analysis of the many forms of injustice is needed. These data become part of the hermeneutics used to look at texts, teachings, and practices in a wide range of religions as the circle of theory and praxis spins.

Gender, anti-racism, and related analyses present a serious challenge for those who perceive religions as unchanging. Such fundamentalism is common across the religious spectrum. But for those who join Catholic moral theologian Daniel C. Maguire in affirming "the renewable moral energy of religion" (2000, p. 10) there is considerable latitude for reforming traditions based on emerging social and biological data, and for joining with those who profess no religious faith whatsoever. We recognize that the same religions that are the source of visions and impetus for justice can also be barriers to their accomplishment. This is a fraught and vexed but real situation that shapes contemporary social

Journal of Feminist Studies in Religion. Available in: < http://www.iupress.indiana.edu/pages. php?pID $=84 \&$ CDpath $=4>$.

2 Mary E. Hunt quoted in Charlotte Bunch (1987, p. 140). 
change work that is religiously grounded.

Feminist spirituality is an umbrella terms for how this renewed moral energy plays out. Liturgies and rituals are among the primary ways most people meet religion-when their mother dies, their baby gets sick, or their community wants to commemorate weddings, funerals, and other liminal events. Inclusive language about the divine and broad inclusion of human experiences make all the difference as to whether some people can pray or not. But efforts in Christianity, for example, to move beyond the "Father, Lord, Ruler, King" vocabulary for the divine, especially in hymns and preaching, have been largely unsuccessful. Mainline denominations, even relatively progressive ones, have made little progress on shifting out of patriarchal patterns.

Nonetheless, many women-led religious groups work in the political

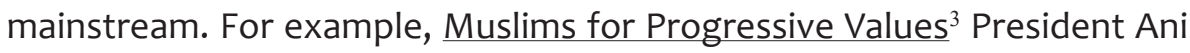
Zonnenfeld discusses women imams and queer Muslims in popular media. The Jewish Orthodox Feminist Alliance", founded by Blu Greenberg, is made up of Orthodox Jewish women "expand[ing] the spiritual, ritual, intellectual, and political opportunities for women with the framework of halakha," or Jewish law. These are all foundational, successful challenges to major religious traditions on the basis of gender that have concrete expressions in daily life.

But they do not stop with so-called women's issues. NETWORK Lobby for Catholic Social Justice ${ }^{5}$, now known for its "nuns on the bus" who travel widely to spotlight women-led social justice efforts, has a broad agenda. Executive Director Sister Simone Campbell took signatures of 7,000 nuns to Senator Mitch McConnell against the repeal of Obamacare that she and her colleagues had been instrumental in passing despite the opposition of the Catholic Bishops. The women became the public face of American Catholicism, much to the consternation of the bishops. If feminists in religion had not made possible and visible women as religious agents or protagonists in patriarchal tradition like Islam, Judaism, and Catholicsm, these activists would not be recognized

\footnotetext{
See: $<$ https://www.mpvusa.org/ >.

See: $<$ https://www.jofa.org/ >.

See: $<$ https://networklobby.org/ $>$.
} 
in the public arena as religious leaders.

Feminist scholarship in religion has its own activist component. In the summer of 2017, Feminist Studies in Religion Inc. (which publishes the Journal of Feminist Studies in Religion among other activities) gathered scholars/activists to consider "Making Alliances, Breaking Taboos, Transforming Religions." It was a rich opportunity to hear from colleagues from several countries and realize how hard it is to do this work across race, class, age, religions, nationalities, and other identities.

Elisabeth Schüssler Fiorenza (2016), renowned feminist biblical scholar at Harvard University, published Congress of Wo/men: Religion, Gender, and Kyriarchal Power, an exposition of the political dynamics involved in feminist studies in religion. She criticizes some feminist scholars for leaving aside religions as a resource for social change. At the same time, she calls out some religious feminists for universalizing arguments that pass over the fact that women are quite unique and diverse. But her focus, while theoretical, is also innately practical as the damage of religious fundamentalisms becomes apparent in legislation and public policy.

It is important to point out that at the outset of feminist studies in religion scholars assumed they knew what a woman was and what a man was. Today, there is no reason to be confident. Transgender persons have changed all of that. The diverse and fluid nature of both gender identity and sexual orientation, and the natural and nurtured components of each, is widely acknowledged. For example, if a lesbian woman in a relationship decides to become a man, does that make his partner heterosexual all of a sudden? If a man transitions to being a woman, does she experience sexism the same way as those who are born women? Religiously reinforced notions of sex and gender gone awry cause serious harm. Queer studies in religion is an evolving field that traces its roots to early feminist work.

6 FEMINIST STUDIES IN RELIGION. Making Alliances, Breaking Taboos, Transforming Religions: A Feminist Studies in Religion Visioning Conference, June 18 - 21, 2017 Drew University, Madison, NJ. Feminist Studies in Religion. Available in: < https://www.fsrinc.org/web-articles/feminist-studies-in-religions-2017-conference-making-alliances-breaking-taboos-transforming-religions/ >. 
An early project that began important conversations in this regard resulted in the book entitled Good Sex: Feminist Perspectives from the World's Religions (Patricia JUNG, Mary E. HUNT, Radhika BALAKRISHNAN, 2001). A dozen scholars from eight countries and six religious traditions addressed ourselves to the question what women think of as "good sex." Virtually every religious answer to the question that we had studied came from male perspectives. Indeed, women's answers were different. For instance, I addressed from a Catholic perspective "Just Good Sex," linking the goodness of sex with the goodness of having housing, food, a job, with the goodness of safety and consent (Patricia JUNG, Mary HUNT, Radhika BALAKRISHNAN, 2001, p. 158-173). A Jewish colleague, Rebecca Alpert, took on the matter of taboos, when something is good because it is bad (Patricia JUNG, Mary E. HUNT, Radhika BALAKRISHNAN, 2001, p. 31-43). A Muslim writer, Pilar Ilkkaracan looked at Islam and women's sexuality in a pioneering essay on the topic (Patricia JUNG, Mary E. HUNT, Radhika BALAKRISHNAN, 2001, p. 61-76).

Another such project was Heterosexism in Contemporary World Religion: Problem and Prospect edited by Marvin Ellison and Judith Plaskow (2007). Authors from a range of religious traditions explored not homosexuality, about which so much has been written in religion, but heterosexism, a far less studied but deeply problematic theme. That change in gaze is crucial. It meant the difference between from looking at what from a patriarchal perspective was considered problematic (homosexuality) to what from a feminist perspective represented a change in power, a change in whose views matter. The result was a totally different study that was explicitly helpful to those who are marginalized.

\section{FEMINIST SPIRITUALITY AS A SOCIAL FORCE}

As religions change on the basis of this kind of feminist work, as their "renewable moral energy" is unleashed, there is a concomitant increase in social change. At the same time, Pew Research shows a sharp decline of participation in mainline traditions (Michael LIPKA and David MCCLENDON (2017). It is interesting to look at cases where those who attend to matters of gender, both within and beyond religions, work together for social change based on feminist commitments. 
One such example was the January 2017 Women's March on Washington. Large numbers of people, mostly women, took to the streets to reject in public and wholesale terms the values of greed and "America first" that were articulated in what they perceived as sexist, white supremacist, xenophobic statements and policies of the newly inaugurated president and his administration. Marches were held around the globe on January 21,2017 , the day after the inauguration of the $45^{\text {th }}$ president of the United States.

For many people, the sense of disbelief following the election gave way to despair. It was a bitterly disappointing win by a candidate who distinguished himself by his crude and crass behavior toward women, on top of an unfolding policy agenda including rolling back climate change remedies, favoring torture, walls, and aggression. Spiritual malaise set in for many people. The feminist organizers' genius insight was to invite and ignite people for action.

The March was an expression of feminist civil religion which was led not by the usual male priests, ministers, imams, and rabbis who traditionally preside at such events, or even by male political leaders who are invested with that stature in a more secular turn. Rather, this March was led by women of many and no religious affiliation. Millions of people participated. A huge crowd gridlocked Washington, D.C. for hours. It kicked off what would become four years of opposition to madness, lies, and social disintegration.

Sociologist Dana Fisher, in a careful look at this and subsequent marches, found that the resistance did not slow down (Sarah KAPLAN, 2017). So-called "protest fatigue" did not set in as many who marched for women also marched later for science, the environment, and then for immigrants, Black Lives Matter, and LGBTIQA rights. This does not surprise spiritual feminists who have long insisted on an intersectional analysis and interstructured solutions to myriad social problems. These marches are an example of putting a feminist approach to the service of social change.

The role of religion and spirituality in all of this is telling, though not in the measurable ways of how many people belong to religious group $\mathrm{X}$ or the percentage of those who practice faith $\mathrm{Y}$. Rather, religion and 
spirituality in the broadest sense of what connects people were on the march in postmodernity, clearly a product of feminist and other liberationist deconstructions. The very act of gathering was a spiritual statement. These marches and rallies were not feel-good fests, but serious, if at times light-hearted, manifestations of people who are working to create a just world. No arrests were reported during the January D.C. march despite the estimated million participants.

Speeches and music (not sermons or hymns) added content to these marches. Pink knit hats with cat ears were worn as a statement against sexual violence. The arts were prominent as posters, sculptures, music, and dance added dimensions. But the heart of the matter was being there, showing up, embodying something that puts the brakes on the dismantling of affordable health care, bans on immigrants, violence against people of color, and lower tax rates for wealthy people.

The role of organized religion was relatively minor in these actions. Unlike their predecessors during the Civil Rights and anti-Vietnam war protests, male clergy and religious leaders were not generally in the vanguard of the marches though some religious people spoke at rallies. The lead groups of the Women's March in D.C. were Planned Parenthood (women's health), the Natural Resources Defense Council (climate change and fossil fuels), Emily's List (electing pro-choice Democratic women candidates), and NARAL Pro-Choice America (choosing abortion, birth control, sex education, and healthy pregnancies).

The so-called Religious Left has enjoyed a bit of a renaissance in recent years. But in its institutional expressions, like the National Council of Churches, Sojourners, even the Moral Monday groups, it remains largely patriarchal in substance. That means mainly male leadership without primary attention to issues of women's well-being, especially reproductive justice, including legal abortion. It is a silo approach to issues rather than the intersectionality of feminism. And, it means a preponderance of language, imagery, hymns, and preaching that are replete with 'Lord', 'Father', 'Ruler', and 'King' as if decades of feminist work to diversify religions had never happened.

There are partner groups of many stripes in current organizing including those working against gun violence, in favor of girls' education, 
promoting peace and environmental issues. Religious groups are among them, but most often they come from the margins of their traditions rather than from their institutional hearts. For the Women's March, several Jewish organizations, Unitarians, the Federation of Protestant Welfare Agencies, Catholics for Choice, and Faith in New York were among the official partners, few of them representing official denominational religious entities.

Feminist spirituality is one of the most useful explanatory constructs for talking about the 'products' of feminist studies in religion. What brings many people together is not a particular dogma or doctrine. To the contrary, participation in organized religions is on the wane in the U.S. with 'nones,' meaning people who affiliate with none of the major religious traditions, far outpacing 'nuns' for new members.

Vision and hope are lived out in multiple ways, which need not be competing or mutually exclusive. But a feminist way of thinking about the world, as if there is no one right answer, no single correct route from birth to death, no unified worldview is not what most people hear from their patriarchal religious traditions. Instead, they are taught to follow The Way, The Path, or some other unitary approach that smacks more of concern about market share, how it will draw members into the religious organization, than about helping people find ways to live out their commitments in solidarity with others. That is how feminist work is different.

The challenge of twenty-first century religion is to find ways to live with many different, sometimes overlapping, ways of being in community. It is not easy, but the many forms of activism prove that many people are willing to try. That is what feminist spirituality looks like walking down the street. Living with the discomfort of diversity in order to move forward is not a sign of cheap relativism, but a hallmark of feminist efforts. Without abandoning one's beliefs, it is possible to pass over the rigid, narrow foci that have kept patriarchal ecumenical and interfaith efforts from succeeding. It is not a sign of rampant secu-

In U.S, Decline of Christianity Continues at Rapid Pace: An update on America's changing religious landscape. Pew Research Center. October 17, 2019. Available in: < https://www.pewforum. org/2019/10/17/in-u-s-decline-of-christianity-continues-at-rapid-pace/ > . 
larization but evidence of reasonable and responsible religiosity. Such forms of spirituality, which are expressed by embracing a shared vision of human flourishing and cosmic harmony, result from the deconstruction of patriarchal religions.

Calling this 'spirituality' does not relegate it to a mystical realm or get one off the hook for critical analysis. Instead, this kind of feminist spirituality for the common good is the heart and soul of the human project. Feminist spiritualities, in all of their diversity of expression and priorities, in all of their performative power and interreligious richness, spark and sustain social change work in ways that patriarchal religions, especially Christianity, Judaism, and Islam, did in previous centuries.

\section{MOVING FORWARD WITH FEMINIST THEOLOGIES}

Fifty years into the work of feminist theologies, there are thousands of books, articles, classes, and research projects on subjects ranging from language, leadership, exegesis, history, ethics, liturgy, ministry, and spirituality in virtually all of the world's major religions in amazing quantity, complexity, and variety. What began as a dominantly white Christian and Jewish field is now exponentially diverse as colleagues from Islam, Buddhism, Pagan/Wiccan groups, Indigenous religions, Hinduism, and many other traditions including the 'spiritual but not religious,' the nones (none of the above), and 'the never agains.' Their common focus is on finding meaning and value in human life that coheres with political and social commitments. These groups, as well as many others around the world, point to a bright future for feminist theologies despite backlash and obstacles.

Still, there is precious little material on how to share faith with children. There is even less on how to have hard conversations with people who are actively hostile to women's equality and racial justice. Economic recession is hitting academic women's studies and denominational women's offices hard. Given these needs, where will the next wave of work come from?

Feminists in religious studies have various starting points. Several will suffice to give the flavor and invite further research. One important group is the Katie Geneva Cannon Center for Womanist Leadership ${ }^{8}$.

See: $<$ https://www.upsem.edu/cwl/ >. 
Named for deeply respected pioneer in womanist studies Dr. Kate G. Cannon (1998), this new group prioritizes the work of Black women in ministry_preaching, teaching, counselling with attention to the needs of Black people-out of which they theologize. Their conferences and classes are preparing new cohorts of womanist leaders both for Black churches and for the academy. The center is located at a seminary, so it is well poised to contribute to the future of theological education.

Women Spirit Ireland ${ }^{9}$, also called The Institute for Feminism and Religion, is another such group. Led by feminist theologian Mary Condren, it "aims to explore a prophetic approach to feminism and religion, inclusive of many traditions and emerging consciousness in Ireland." Their programs, especially on Brigit and The Cailleach, have global participation. They offer foundational thinking about feminist themes in religion: for example, the importance of mercy not sacrifice, the centrality of indigenous spirituality rather than imposed frameworks.

The Pacific, Asian, and North American Asian Women in Theology and Ministry (PANAAWTM) ${ }^{10}$ has a long history of meetings and conferences, anthologies and support for single authored books produced by its members. Postcolonial work from several Asian and Asian American perspectives is emblematic of PANAAWTM's offerings. Their combination of academic and ministerial concerns, their clearly intersectional analysis and activism, and their enduring commitment to feminist studies in religion make them an important locus of this work.

Journal of Feminist Studies in Religion ${ }^{11}$, and the related blogs, social media presence, and publishing project of the umbrella Feminist Studies in Religion, Inc. ${ }^{12}$ is a longtime sustaining presence in the field. More than thirty-five years of publishing high-quality scholarship, poetry, and reporting make JFSR the journal of record. FSR, Inc.'s gatherings, books, and sustained public conversations provide benchmark scholarship accessible to scholars and activists alike.

\footnotetext{
See: < https://womanspiritireland.ie/ >.

See: < https://www.panaawtm.org/ >.

See: < https://www.fsrinc.org/the-jfsr/ >.

See: < https://www.fsrinc.org/ >.
} 
The Women's Alliance for Theology, Ethics and Ritual (WATER) ${ }^{13}$ has been one of the go-to-place for feminist studies in religion for thirty-five years. WATER is part of the "New Space" in feminist philosopher Mary Daly's words, where the academic study of religion meets the real needs of people seeking spiritual lives. Whether a woman minister comes for spiritual direction or a graduate student uses the library for his feminist research, whether a Mennonite intern or an Icelandic scholar arrives, the many and varied people who have come to WATER and who now join by Zoom constitute the Alliance.

WATER has had more than eighty interns including Catholics, Protestants, Buddhists, Muslims, Jews, and those who profess no religious faith whatsoever, who are now doing their work in many fields. Monthly offerings both spiritual and intellectual produce a wide array of resources that can be used by colleagues in the field.

\section{CONCLUSION}

These groups, and so many more that deserve mention, portend a bright future for feminist theologies and related activities. Technology, social media, podcasts, webinars, and the like will accelerate the rate of change, the speed with which new ideas about diverse and inclusive ways of being religious will take hold. Essential to make this happen is the empowerment of young scholars through scholarships, internships, and jobs so that their full energies can go into creating according to their generations' experiences.

The rise of "spiritual but not religious" people, "nones" or "never agains" as the categories evolve, means that work on gender and religion, indeed all of the interstructured particularities which now constitute a feminist perspective, must be done in concert with people who are not religious. One way that conversation happens is through shared social action like the marches, political campaigns, lobbying efforts, and voter registration where beliefs are articulated by actions, not actions dictated by beliefs.

Major historical religious traditions like Christianity and Judaism are not to be forgotten despite the barriers some of them have against

13 See: < https://www.waterwomensalliance.org/ >. 
gender equality in religion. When they do embrace critical feminist analysis, these can be fonts of vision and creativity that are rich and deep. Religious art, music, and rituals, all of which are being reimagined according to women's feminist lights, add considerable texture to societies. Sacred texts that are under deep renovation by scholars can be sources of inspiration.

Then it is not hard to imagine newly minted coalitions of religious people who are gender-inclusive, in economic solidarity with one another, anti-racist, pro-sex, speaking diverse languages, and using many forms of media. They provide support and inspiration for social change which goes beyond what any one faith tradition can offer. Then it is clear that feminist religious dynamism and action resulting from feminist theologies of may stripes can make a world of difference, a different world.

\section{REFERENCES}

BUNCH, Charlotte. Passionate Politics: Feminist Theory in Action. New York: St. Martin's Press, 1987.

CANNON, Katie Geneva. Katie's Canon: Womanism and the Soul of the Black Community. New Tork: Continuum, 1998.

DALY, Mary. Beyond God the Father: Toward a Philosophy of Women's Liberation. Boston: Beacon Press, 1993.

ELLISON, Marvin and PLASKOW, Judith. Heterosexism in Contemporary World Religion: Problem and Prospect. Cleveland: Pilgrim Press, 2007.

FEMINIST STUDIES IN RELIGION. Making Alliances, Breaking Taboos, Transforming Religions: A Feminist Studies in Religion Visioning Conference June 18 - 21, 2017 Drew University, Madison, NJ. Feminist Studies in Religion. Available in < http://www.fsrinc. org/blog/events/making-alliances-breaking-taboos-and-transforming-religions/ >.

GAGE, Matilda Jocelyn. Woman, Church and State: A Historical Account of the Status of Woman through the Christian Ages. Chicago: C. H. Kerr, 1893.

GOLDSTEIN, Valerie Saiving, The Human Situation: A Feminine View. The Journal of Religion, v. 40, n. 2, 1960, pp. 100-112.

In U.S, Decline of Christianity Continues at Rapid Pace: An update on America's changing religious landscape. Pew Research Center. October 17, 2019. Available in <https:// www.pewforum.org/2019/10/17/in-u-s-decline-of-christianity-continues-at-rapid-pace/>. JUNG, Patricia Beattie; HUNT, Mary E.; BALAKRISHNAN, Radhika (Eds.). Good Sex: Feminist Perspectives from the World's Religions. Piscataway: Rutgers University Press, 2001. 
KAPLAN, Sarah. A scientist who studies protest says 'the resistance' isn't slowing down. Available in: < https://www.washingtonpost.com/news/speaking-of-science/

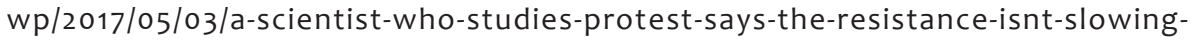
-down/?utm_term=.eab2of7322b2 >.

LIPKA, Michael; MCCLENDON, David. Why people with no religion are projected to decline as a share of the world's population. Available in: < http://www.pewresearch. org/fact-tank/2017/04/07/why-people-with-no-religion-are-projected-to-decline-as-a-shareof-the-worlds-population/ >.

MAGUIRE, Daniel C. Renewable moral energy of religion. Sacred Energies, Minneapolis, MN: Fortress Press, 2000.

"Making Alliances, Breaking Taboos, Transforming Religions" A Feminist Studies in Religion Visioning Conference June 18 - 21, 2017 Drew University, Madison, NJ. Feminist Studies in Religion. Available in < http://www.fsrinc.org/blog/events/making-alliances-breaking-taboos-and-transforming-religions/>

PEW RESEARCH CENTER. In U.S, Decline of Christianity Continues at Rapid Pace: An update on America's changing religious landscape. Pew Research Center. October 17, 2019. Available in: < https://www.pewforum.org/2019/10/17/in-u-s-decline-of-christianity-continues-at-rapid-pace/ $>$.

SAN MARTíN, Inés. Pope calls gender theory a 'global war' against the family. Crux, October 1, 2016. Available in: < https://cruxnow.com/global-church/2016/10/01/pope-calls-gender-theory-global-war-family $>$.

SCHÜSSLER FIORENZA, Elisabeth. Congress of Wo/men: Religion, Gender, and Kyriarchal Power. Cambridge: Feminist Studies in Religion Books, 2016.

STANTON, Elizabeth Cady. The Woman's Bible. New York: European Publishing Co., $1895-98$.

Submetido em: 3-8-2021

Aceito em: 4-11-2021 